УДК 17.022.1:140.8

DOI:

Надія Ашиток, доктор філософських наук, професор кафедри загальної педагогіки та дошкільної освіти Дрогобицького державного педагогічного університету імені Івана Франка Юрій Галь, кандидат фізико-математичних наук, доиент кафедри математики, директор інституту фізики, математики, економіки та інноваційних технологій Дрогобицького державного педагогічного університету імені Івана Франка

\title{
ПРОБЛЕМИ ВПРОВАДЖЕННЯ ЦИФРОВИХ ТЕХНОЛОГІЙ В ДИСТАНЦЙНЕ НАВЧАННЯ У ВИЩІЙ ШКОЛІ
}

У статті зазначається, щчо ичифровізація зумовлена не лиме карантином, а й загальним розвитком країн світу. Цифрові технології використовувались в освіті й раніше, проте зараз їхня роль значніша. В умовах карантину на основі цуих технологій працюють усі різновиди освіти, крім дошкільного. Зазначено, ияо труднощі освоєння циих технологій виникають через відсутність не лише методичної бази їх використання, але й методологї̈ їх розробки, щзо змушує педагога на практиці орієнтуватися на особистий досвід.

Ключові слова: дистаниійне навчання; педагог; пандемія; цчифровізація; ичифрові технології.

Jim. 10.

Nadiya Ashytok, Doctor of Sciences (Philosophy), Professor of the General Pedagogy and Preschool Education Department Drohobych Ivan Franko State Pedagogical University Yuriy Hal, Ph.D.(Physics and Mathematics), Associate Professor of the Mathematic Department, Director of the Institute of Physics, Mathematics, Economics and Innovative Technologies Drohobych Ivan Franko State Pedagogical University

\section{PROBLEMS OF INTRODUCTION OF DIGITAL TECHNOLOGIES IN DISTANCE LEARNING IN HIGH SCHOOL}

The article notes that digitalization is due not only to quarantine, but also to the general development of the world in the post-classical era. Digital technologies have been used in education before. However, now their role is more significant. In the conditions of quarantine on the basis of these technologies all kinds of education work, except preschool. The purpose of the article is to consider the problems of organizing distance learning based on digital technologies, the use of which is due not only to the emergency, namely the pandemic, but also the need to train professionals who will work in the future with these technologies.

It is noted that the difficulties of mastering digital technologies in education arise due to the lack of not only a methodological basis for their use in this area, but also a methodology for developing these technologies for education, which forces teachers to focus on personal experience and ability to empirically seek ways to use digital technologies. It turned out that teachers use presentation preparation programs, word processors, spreadsheets, database management systems, e-mail, chats, etc. in order to organize distance learning. Teachers organize audio and video conferences using special equipment and software via the Internet. Technologies such as video and audio recording are important for the distance learning system.

It is concluded that digital technologies make it possible during a pandemic to provide remote interaction between teachers and students. Nowadays, a type of modern teacher is being formed who must not only have knowledge in the field of these technologies, but also be able to apply them in professional activities. A lot of digital technologies have been developed, but new approaches to distance learning should be sought to improve the quality of education.

Keywords: distance learning; teacher; pandemic; digitalization; digital technologies.

П остановка проблеми. Пандемія короновірусу стала потужним стимулом впровадження цифрових технологій в усі сфери економічного і соціального життя. Карантинні заходи спровокували переміщення в онлайн-середовище не лише значної частини торгівлі товарами та соціальними послугами, а й розвиток освіти на основі цифрових технологій. Звісно, цифровізація зумовлена не лише карантином, а й загальним розвитком країн світу в постнекласичну епоху. Цифровізація, яка набуває в останні десятиліття глобальний характер, стала одним із стратегічно важливих векторів розвитку цивілізації, результати яких ми 


\section{ПРОБЛЕМИ ВПРОВАДЖЕННЯ ЦИФРОВИХ ТЕХНОЛОГЙ}

В ДИСТАНЦЙНЕ НАВЧАННЯ У ВИЩІЙ ШКОЛІ

повсюдно спостерігаємо сьогодні і які у майбутньому визначатимуть характер нової цивілізації - глобального інформаційного суспільства. У контексті загальних світових тенденцій цифрові технології використовувались в освіті й раніше, проте зараз їхня роль значніша - в умовах карантину на основі цих технологій працюють усі різновиди освіти.

Аналіз останніх досліджень і публікацій. Актуальність осмислення зазначених технологій на етапі становлення нової цивілізації і під час пандемії не згасає, хоча й присвячено цій проблематиці чимало праць. Дослідженню уявлень про постнекласичну епоху суспільного розвитку та технологічних і соціокультурних змін присвячені студії Д. Белла, Е. Тоффлера, I. Масуді, Дж. Гелбрейта,Е.Гідденса, Г.Маклюєна,М.Кастельса, Т. Стоун'єра та ін. Головними факторами реформування системи освіти у зазначений період, як уважають Н. Ж. Шайтова і М. Г. Туленгалієва, $\epsilon$ такі: доцільність переходу суспільства до нової стратегї̈ розвитку на основі знань та високоефективних цифрових технологій, можливість успішного розвитку суспільства 3 опорою на високу освіченість і ефективне використання цифрових технологій, тісний зв'язок між рівнем добробуту нації, національної безпеки держави та станом освіти і використанням зазначених технологій [10]. У численних публікаціях відзначаються недоліки і переваги впровадження цифрових технологій в освіту [1, $11-15 ; 2,85-88 ; 8 ; 10]$. О. Шпунт, зокрема, до переваг відносить можливість створення принципово нової моделі навчання - дистанційної, яка грунтується на використанні новітніх цифрових технологій, здатних забезпечити обмін навчальною інформацією на відстані (комп'ютерний зв'язок, супутникове телебачення тощо) [10]. С. Пахоніна докладно зупиняється на аналізі проблем, що виникають у результаті дистанційного формату навчання. До цих проблем вона відносить насамперед технічні, зазначаючи, що не виявилося належного технічного оснащення, підтримки й виходу в Інтернет в умовах самоізоляції та дистанційної роботи, особливо за межами районних і обласних центрів. Друга проблема управлінська, що проявляється у недостатній організації дистанційного формату роботи, навчання, попередньої підготовки кадрів, освоєння онлайн-технологій та їхнього впровадження чи у неможливості впровадження їх “вдома" через технічні проблеми. Відстань між співробітниками, викладачами і здобувачами освіти, що навчаються, окреслила проблему особистої відповідальності, самостійності у навчанні, освоєнні нових видів та форм роботи. Третя проблема - психологічна, адже цифровізація часто спричиняе постійний стрес через нові розпорядження, не завжди задовільну організацію дистанційної роботи та звітності, підвищене навантаження, віддаленість від робочого місця, технічні проблеми та відповідальність за успішність здобувачів освіти, престиж організації. Четверта проблема висвітлює ускладнення при засвоєнні знань, їхньому розумінні, закріпленні та відтворенні, застосуванні на практиці [8]. О. Майборода окреслює основні проблемні моменти на шляху впровадження системи дистанційної освіти в Україні і фактори, які гальмують розвиток цієї перспективної форми навчання [6]. I. Ляшенко, аналізуючи переваги дистанційного навчання і можливі перешкоди в організації і здійсненні такого навчального процесу, акцентує увагу на необхідності розробити гнучку й ефективну систему дистанційного навчання. А це означає, що потрібно забезпечити інформаційну й методологічну освітню базу та підготувати висококваліфікованих фахівців для здійснення дистанційного процесу навчання [5]. І. Голоденко та Є. Корнєєва підкреслюють необхідність правового регулювання процесу надання освітніх послуг в Україні в умовах пандемї COVID. Зазначене регулювання, на думку дослідниць, має здійснюватись з урахуванням того, що активізація дистанційної форми навчання в Україні - це вимушений захід, пов'язаний $з$ упровадженням карантинних обмежень, а не стратегія повсюдного впровадження в освітній процес вказаної форми навчання. Водночас, оскільки у сучасному світі існує загроза виникнення нових пандемій, варто розробити та закріпити на законодавчому рівні спеціальні норми, спрямовані на врегулювання надання освітніх послуг закладами освіти в умовах пандемій [3]. Незважаючи на досить грунтовне вивчення різних аспектів застосування цифрових технологій в системі освіти під час пандемії, деякі проблеми потребують докладного дослідження. Зокрема, це стосується організації дистанційного навчання. А тому мета статті - розглянути проблеми організації дистанційного навчання на основі цифрових технологій, використання яких зумовлене не лише надзвичайною ситуацією, а саме пандемією, але й необхідністю підготовки фахівців, які у майбутньому будуть працювати із застосуванням цих технологій у різних сферах життєдіяльності людини.

Виклад основного матеріалу. Як слушно зазначають Н. Шайтова і М. Туленгалієва, труднощі освоєння цифрових технологій в освіті 


\section{ПРОБЛЕМИ ВПРОВАДЖЕННЯ ЦИФРОВИХ ТЕХНОЛОГЙ В ДИСТАНЦЙНЕ НАВЧАННЯ У ВИЩІЙ ШКОЛІ}

виникають через відсутність не лише методичної бази їх використання в цій сфері, але й методології розробки даних технологій для освіти, що змушує педагогів на практиці орієнтуватися лише на особистий досвід і вміння емпірично шукати шляхи ефективного застосування цих технологій [9].

Емпіричний досвід, отриманий під час впровадження цифрових технологій в систему освіти, показав їх великі можливості для організації дистанційного навчання [10]. Водночас, під час процесу впровадження було виявлено чимало проблем. Це значно більша вартість організації дистанційного навчання у порівнянні 3 традиційними технологіями, що пов'язано з необхідністю використання значної кількості технічних (комп'ютери, модеми тощо) та програмних (підтримка технологій навчання) засобів, а також 3 підготовкою додаткових організаційно-методичних посібників (спеціальні інструкції для осіб, що навчаються, і викладачів тощо), нових підручників і навчальних посібників у цифровому форматі.

Звісно, педагогами здійснюється пошук підвищення якості навчання і нових форм використання цифрових технологій в освітньому процесі. Ними при організації дистанційного навчання використовуються програми підготовки презентацій, текстові процесори, електронні таблиці, системи управління базами даних, графічні пакети тощо. Через глобальну комп'ютерну мережу Internet для них доступні світові інформаційні ресурси (електронні бібліотеки, бази даних, сховища файлів тощо). Учасники навчально-виховного процесу під час дистанційного навчання використовують й інші засоби інформаційних та комунікаційних технологій - електронну пошту, чати, які дають можливість спілкуватися у режимі online. За допомогою спеціального обладнання i програмного забезпечення через Інтернет організовуються аудіо- і відео конференції. Цифрові технології роблять можливим доступ до навчальнометодичної та наукової інформації; допомагають організовувати i моделювати науководослідницьку діяльність, проводити навчальні заняття. Для системи дистанційного навчання значними $є$ такі технології, як відеозапис та аудіозапис. Ще одна технологія - освітні електронні видання 3 Інтернету або ті, що зберігаються на цифрових носіях. Педагоги та особи, що навчаються, можуть здійснювати віртуальні екскурсії світовими галереями, користуватися матеріалами електронних архівів, каталогів та бібліотек [10].
Педагоги під час організації дистанційного навчання використовують технології, які можна по-різному класифікувати. Значний інтерес при класифікації цих технологій має підхід, запропонований В. Домрачевим та І. Ретинським. Ними враховувалася дидактична спрямованість технологій. 3 цієї точки зору цифрові технології розрізняються за способом отримання знань, ступенем інтелектуалізації, цілями навчання, характером управління пізнавальною діяльністю користувачів у комп'ютерній навчальній програмі. За способом отримання знань розрізняються декларативні і процедурні способи. Технології декларативного типу орієнтовані на надання $і$ перевірку знань у вигляді фрагментів інформації. До них можна віднести ті, в основі яких лежить використання цифрових підручників, навчальних баз даних, тестових і контролюючих програм. Технології процедурного типу будуються на основі моделей, за допомогою яких можна отримувати знання у конкретній предметній сфері. До цих технологій можна віднести технології, що використовують пакети прикладних програм, лабораторні практикуми, ігрові програми. За ступенем інтелектуалізації цифрові навчальні технології умовно поділяються на два види: системи програмованого навчання та інтелектуальні навчальні системи. Системи програмованого навчання передбачають отримання порцій інформації (текстової, графічної, відеоінформації) у певній послідовності і способі контролю іiі засвоєння за темами навчального курсу. Інтелектуальні навчальні системи характеризуються такими особливостями, як адаптація до знань та особливостей користувачів, гнучкість процесу навчання, вибір оптимального навчального впливу, визначення причин помилок. За цілями цифрові навчальні технології поділяються на такі види: навчання навичкам використання конкретних методів у практичній діяльності, отримання та систематизація різних фактичних даних; навчання аналізу інформації, iї систематизації, творчості, методика проведення дослідження. За характером управління пізнавальною діяльністю під час роботи 3 педагогічними програмними продуктами технології поділяються на лінійні, розгалужені, а також комбіновані програми, що містять усі зазначені ознаки [4].

Технології навчання у вищій школі істотно відрізняються від шкільних. Вони спрямовані не лише на передавання і сприймання знань, визнаних науковою спільнотою та освітянамипрактиками, а й на відображення сучасного етапу розвитку науки, розкриття ії методологічних засад, 


\section{ПРОБЛЕМИ ВПРОВАДЖЕННЯ ЦИФРОВИХ ТЕХНОЛОГІЙ В ДИСТАНЦЙНЕ НАВЧАННЯ У ВИЩІЙ ШКОЛ}

ознайомлення з пошуками науковців-дослідників у педагогічній сфері. В умовах дистанційного навчання актуально не лише зберегти зазначену специфічність навчання у вищій школі і не втратити здобутки освітньої практики, а й збагатити ії̈ знахідками, ефективними при onlineнавчанні.

Сучасні заклади вищої освіти будують процес навчання студентів на основі поєднання різних форм його організації. Основними є такі: лекції, практичні, семінарські, лабораторні заняття, спецкурси, спецсемінари, педагогічна практика, консультації, колоквіуми, контрольні, курсові й дипломні роботи. Суттєвих відмінностей між впровадженням цих форм у дистанційне та аудиторне навчання немає, хоча деяка специфіка все ж таки існує. Наприклад, провідною серед зазначених форм у закладі вищої освіти є лекція. У практиці вищої школи розрізняють лекції за дидактичними завданнями - вступні, тематичні, оглядові, настановчі, заключні; за способом викладу - проблемні, лекції-візуалізації, бінарні лекції (лекції-дискусії), лекції із заздалегідь запланованими помилками, лекції-консультації; лекції-прес-конференції, лекції "Круглий стіл", лекції-анкети, лекції-диспути, лекції-брифінги, мінілекції, лекції-бесіди (діалоги з аудиторією), лекції з розбором конкретних ситуацій, лекції із застосуванням техніки зворотного зв'язку, багатоцільові та ін. Під час дистанційного навчання можуть проводитися всі ці види лекцій. Специфіка їх впровадження в дистанційну практику полягає лише у формах технічного оформлення. Такими формами є: лекція може оформлятися у вигляді презентації, під час якої викладач читає лекцію $з$ монітора, а студенти у цей час записують основне; лекція може подаватися на моніторі текстовими тезами, які викладач доповнює своїми коментарями; тези лекції можуть ілюструватися на моніторі малюнками, таблицями, діаграмами тощо; лекція може читатися традиційно усно і супроводжуватися ілюстративним матеріалом на моніторі, наприклад, серією таблиць; текст лекції викладач може пересилати студентам на електронну пошту заздалегідь, а під час заняття пояснювати лише складні питання; окремі лекції можуть пересилатися студентам для самостійного опрацювання, а аналіз їх змісту і перевірка засвоєного виноситися на практичне заняття. В усіх випадках електронний варіант лекції, який демонструється на моніторі або пересилається студентам електронною поштою, має починатися з чітко сформульованої теми, плану, текст лекції має бути поділений на фрагменти згідно із зазначеним планом, завершуватися лекція має короткими змістовними висновками.

Серед семінарських занять найпоширенішими $\epsilon$ такі: повідомлення, розгорнута бесіда, доповідь, обговорення рефератів і творчих робіт, коментоване читання, розв'язування задач, диспут, конференція тощо. При дистанційному навчанні відповіді студентів можуть ілюструватися малюнками, картинками, таблицями, відеозаписами тощо. Під час проведення семінару-диспуту, семінару-пресконференції тема заняття та окремі тези для обговорювання бажано виносити на монітор.

На практичних заняттях можуть пропонуватися перевірка теоретичного матеріалу у формі усної відповіді, вправи, тести за пройденою темою, неігрові методи (аналіз конкретних ситуацій, вирішення педагогічних завдань, розбір документації, дії за інструкцією), імітаційні методи (ділові, рольові ігри, ігрове проєктування) тощо. Студенти на практичних заняттях можуть повідомляти тези заздалегідь підготовлених ними доповідей або презентацій з вивченої теми.

Важлива роль належить консультаціям, функція яких набуває особливої актуальності при дистанційній взаємодії, оскільки при цьому виді навчання викладачам важливо не лише консультувати студентів перед виконанням певних завдань, а й сприяти організації їх самостійної роботи. При дистанційному навчанні дещо міняється і зміст консультацій, Зокрема, викладач має бути готовим надати необхідну консультацію 3 оформлення електронного варіанту завдання, особливостей роботи певних цифрових платформ, повідомити про послідовність операцій при роботі 3 електронними носіями тощо. Консультація так само, як під час аудиторного навчання, може бути самостійною формою заняття або входити до складу інших форм, наприклад, лекції, практичного заняття, колоквіуму.

3 використанням цифрових технологій можливості організації самостійної роботи студентів розширюються. Самостійна робота 3 науковою і навчально-методичною літературою на паперових носіях зберігається як важлива ланка самостійної роботи студентів загалом, але iii основу тепер складає робота 3 навчальними цифровими програмами, тестуючими системами, інформаційними базами даних тощо.

Колоквіум є однією 3 форм навчання, що передбачає бесіду викладача зі студентами 3 метою з'ясування рівня знань та його підвищення. Здебільшого колоквіум проводиться у кінці навчального семестру, або після вивчення певних теоретичних тем. Для організації колоквіуму 


\section{ПРОБЛЕМИ ВПРОВАДЖЕННЯ ЦИФРОВИХ ТЕХНОЛОГІЙ В ДИСТАНЦЙИЕ НАВЧАННЯ У ВИЩІЙ ШКОЛІ}

доречно переслати студентам на електронну пошту список тем або питань для підготовки до цього виду роботи, а під час колоквіуму демонструвати його на моніторі.

Розроблено чимало цифрових технологій, проте, на наш погляд, для підвищення якості освіти слід здійснювати пошук нових підходів в організації дистанційного навчання, зокрема, у напрямі пошуку інноваційних форм роботи. Одну iз таких форм пропонує П. Моор, який вважає, що доцільним при дистанційному навчанні $\epsilon$ застосовування не класичної схеми: лекції (коли викладач “озвучує” навчальний матеріал) практичні заняття, на яких перевіряється його засвоєння. Набагато корисніше, на його думку, працювати за такою схемою: студентам попередньо пересилається електронний варіант лекції, а на занятті викладач коментує найбільш складні питання, вивчення яких планується згодом розглянути докладно; наступне заняття присвячується обговоренню проблем, які виникли при вивченні теми, розгляду прикладів [7, 115117]. При такому підході лекції у класичному їх розумінні не проводяться.

Звісно, крім переваг використання цифрових технологій, педагог має враховувати їх зворотний бік. Використання зазначених технологій при дистанційному навчанні може призвести до низки негативних наслідків, серед яких: погіршення фізіологічного стану і здоров'я здобувача освіти; низка психолого-педагогічних проблем (невідфільтрована інформація здатна завдавати психологічної шкоди); зниження мовленнєвої активності здобувача освіти, в результаті чого вона не має достатньої практики мовленнєвого оформлення власних думок. Тривала відсутність активної практики зазначеного виду негативно позначається на процесах мислення. Недоліками застосування цифрових технологій є також більш значні вимоги до педагога (багато здобувачів освіти, мають більш сучаснішу техніку вдома, ніж педагоги; крім того, деякі педагоги не мають навіть мінімальних знань у сфері цифровізації); дослідницька діяльність здобувачів освіти, ускладнена такими причинами: ускладненнями при виборі якісного дослідницького матеріалу з Інтернету, можливістю отримати готовий продукт; недостатньо розробленою технологією самоосвіти для здобувачів освіти; невисокою інформаційною культурою цих осіб і педагогів. Інформаційна культура передбачає перевірку достовірності і якості джерел інформації та недопущення плагіату. Дійсно, при використанні цифрових технологій може спрацьовувати “принцип економії сил”: навіщо витрачати власну енергію і час на підготовку до практичного заняття або лабораторної роботи, якщо Інтернет надає такий багатий вибір, і можна, не витрачаючи зайвих зусиль, отримати готовий розв'язок проблеми.

Висновки. Пандемія вплинула і продовжує впливати на сферу освіти, оскільки раптовий, зумовлений надзвичайною ситуацією перехід до дистанційного навчання поставив педагогів у нові - невідомі раніше умови. Сдине, що вони можуть зробити в цій ситуації, - це використовувати цифрову модель навчання. Варто зазначити, що такий перехід відбувся за неймовірно короткі терміни, проте за часткової наявності ресурсів, це його уможливило. Цифрові технології під час пандемії забезпечують дистанційну взаємодію між педагогами та особами, що навчаються. В умовах цифровізації навчального процесу формується тип сучасного педагога, який має не лише володіти знаннями в галузі цих технологій, а й уміти застосовувати їх у професійній діяльності.

\section{ЛІТЕРАТУРА}

1. Ашиток Н. І. Нова освітня реальність: дистанційна освіта у вищій школі в умовах пандемії. Молодь і ринок. 2021. № 3 (189). С.1115.

2. Ашиток Н.І. Цифровізація дистанційного навчання як виклик сучасності. Вісник Національного авіаційного університету. 2021. № 1 (33). C.85-88.

3. Голоденко I. О. Корнеєва Є. М. Надання освітніх послуг закладами вищої освіти в умовах пандемії коронавірусної хвороби covid-19 (проблемні аспекти). Цивільне право, циивільний nроиес. 2021. №42. URL: http://pd.onu.edu.ua/ article/view/232411

4. Информационные технологии обучения в высшей школе. URL: http://www.profile-edu.ru/ informacionnye-texnologii-obucheniya-v-vysshejshkole.html

5. Ляшенко I. В. Перспективи розвитку дистанційного навчання у вищій школі. Народна освіта. URL: https://www.narodnaosvita.kiev.ua/ ?page $\mathrm{id}=2682$

6. Майборода О. Дистанційне навчання як пріоритетний напрямок вищої освіти. Інформаційні технології $i$ засоби навчання. 2011. №5 (25). URL: https://www.researchgate.net/ publication/341915537_distancijne navcanna ak prioritetnij napramok visoi_osviti

7. Моор П. К. Дистанционное образование: проблемы и перспективы Инновационные технологии в образовании. Материалы IV Международной научно-практической 
видеоконферениии. Тюмень: ТИУ, 2017. С.115117.

8. Пахонина Е. В. К проблеме дистанционной коммуникации. Философские науки. Выпуск № 09(99). 2020. C.64-68. URL: https://researchjournal.org/philosophy/k-probleme-distancionnojkommunikacii

9. Шайтова Н. Ж., Туленгалиева М. Г. Актуальность и проблемы использования информационно-коммуникационных технологий. Materiały X międzynarodowej naukowi-praktycznej konferencji "Naukowa przestrzeń Europy - 2014". Volume 33. Przemyśl. 2014. C. 31-34.

10. Шпунт О. "Плюсы” и “минусы” применения информационно-коммуникационных технологий в образовании. URL: https://pedsovet.org/article/ plyusy-i-minusy-primeneniya-informatsionnokommunikatsionnyh-tehnologiy-v-obrazovanii

\section{REFERENCES}

1. Ashytok, N.I. (2021). Nova osvitnia realnist: dystantsiina osvita $\mathrm{u}$ vyshchii shkoli $\mathrm{v}$ umovakh pandemii [A new educational reality: distance education in higher education in a pandemic]. Youth \& market. No. 3 (189). pp.11-15 [in Ukrainian].

2. Ashytok, N.I. (2021). Tsyfrovizatsiia dystantsiinoho navchannia yak vyklyk suchasnosti [Digitization of distance learning as a challenge of today]. Bulletin of the National Aviation University. No. 1 (33). pp.85-88. [in Ukrainian].

3. Holodenko, I. O. \& Korneieva, Ye. M. (2021). Nadannia osvitnikh posluh zakladamy vyshchoi osvity v umovakh pandemii koronavirusnoi khvoroby covid19 (problemni aspekty) [Provision of educational services by higher education institutions in the context of the covid-19 coronavirus disease pandemic (problematic aspects)]. Civil law, civil process. No. 42. Available at:http://pd.onu.edu.ua/article/view/ 232411 [in Ukrainian].

4. Informatsionnye tekhnologii obucheniya $\mathrm{v}$ vysshei shkole [Information technologies of higher education]. Available at: http://www.profile-edu.ru/ informacionnye-texnologii-obucheniya-v-vysshejshkole.html [in Russian].
5. Liashenko, I.V. Perspektyvy rozvytku dystantsiinoho navchannia u vyshchii shkoli [Prospects for the development of distance learning in higher education]. Public education. Available at: https://www.narodnaosvita.kiev.ua/?page id=2682 [in Ukrainian].

6. Maiboroda, O. (2011). Dystantsiine navchannia yak priorytetnyi napriamok vyshchoi osvity [Distance learning as a priority area of higher education]. Information technologies and teaching aids. No.5 (25). Available at: https://www.researchgate.net/ publication/341915537 distancijne navcanna ak prioritetnij_napramok visoi_osviti [in Ukrainian].

7. Moor, P.K. (2017). Distantsionnoe obrazovanie: problemy i perspektivy Innovatsionnye tekhnologii v obrazovanii [Distance education: problems and prospects Innovative technologies in education]. Materialy IV Mezhdunarodnoi nauchnoprakticheskoi videokonferentsii - Proceedings of the IV International Scientific and Practical Video Conference. Tyumen, pp.115-117. [in Russian].

8. Pakhonina, E.V.(2020). K probleme distantsionnoi kommunikatsii [To the problem of remote communication]. Philosophical Sciences. Vol. 09(99). pp.64-68. Available at: https://research-journal.org/ philosophy/k-probleme-distancionnoj-kommunikacii [in Russian].

9. Shaitova, N. Zh. \& Tulengalieva, M. G. (2014). Aktualnost i problemy ispolzovaniya informatsionnokommunikatsionnykh tekhnologii [Relevance and problems of using information and communication technologies]. Materiaty X międzynarodowej naukowi-praktycznej konferencji "Naukowa przestrzeń Europy - 2014”. Volume 33. Przemyśl. pp.31-34. [in Russian].

10. Shpunt, O. "Plyusy" i "minusy" primeneniya informatsionno-kommunikatsionnykh tekhnologii v obrazovanii ["Pros" and "cons" of the use of information and communication technologies in education]. Available at: $\mathrm{https}: / /$ pedsovet.org/article/ plyusy-i-minusy-primeneniya-informatsionnokommunikatsionnyh-tehnologiy-v-obrazovanii [in Russian].

Стаття надійшла до редакції 17.11.2021

\section{OS8080}

“Кожний новий қрокна шляху прогресу дає нову надію і пов'язаний із подоланням нових труднощів". 